Ann. Biol. anim. Bioch. Biophys., 1979, 19 (2 A), 439-444.

\title{
Catecholamine-containing axons and cell bodies in the hypothalamus of squirrel monkeys
}

par J. BARRY

U. 156 INSERM ef Laboratoire d'Histologie,

Faculté de Médecine,

59045 Lille Cedex, France.

Summary. High concentrations of catecholamine-containing axons have been observed with the Falck-Hillarp technique in the hypothalamus of squirrel monkeys, namely in the periventricular area, preoptic nucleus, arcuate nucleus, premammillary area and dorso medial nucleus.

Catecholamine-containing cell bodies were not found routinely in all animals but have been observed in some of them within the medio-basal hypothalamus and the posterodorsal and rostral hypothalamic areas. This topography suggests that of the $A 12, A 13$, and A14 groups, previously described in other mammalian species.

\section{Introduction}

Monoamine distribution within the central nervous system of primates has been the subject of extensive investigations (Battista ef al., 1972 ; Nobin and Björklund, 1973 ; Felten, 1973, 1976 ; Hoffman, Felten, and Sladek 1976 ; Ishikawa and Tanaka, 1977). However, very few data are available on the hypothalamic topography of monoamine-containing cell bodies.

On the other hand, numerous reactive perikarya of LH-RH neurons have been characterized in various species of monkeys, using immunsera against synthetic conjugated or unconjugated luteinizing hormone-releasing hormone (LH-RH) (Barry and Carette, 1975 ; Zimmerman and Antunes, 1976 ; Silverman et al., 1977 ; Hoffman et al., 1978 ; Barry and Croix, 1978).

The aim of the present research was to compare the distribution of reactive LH-RH neurons with that of catecholamine-containing axons and cell bodies in the hypothalamus of squirrel monkeys under physiological conditions, and the topography of catecholamine-containing cell bodies with that observed in other mammalian species.

\section{Material and methods}

Five young adult female squirrel monkeys (Saimiri sciureus) having an average weight of 500 to $600 \mathrm{~g}$ were supplied by Primate Imports Corp. (New York, USA) for 
this study. They were killed at 2 p. m. and the brains quickly removed. The thin dissected specimens were frozen in propane, prechilled in liquid nitrogen and examined histochemically, using the technique of Fack et al. (1972). The blocks were freezedried for 2 weeks in a Pearse Speedivac Tissue Dryer and treated for 1 to $3 \mathrm{hrs}$. at $80^{\circ} \mathrm{C}$ with Merck formaldehyde (relative humidity $80 \mathrm{p}$. 100). After embedding in paraffin in vacuo, 10 to $20 \mu \mathrm{m}$ thick specimens were cut in the sagittal plane; the sections were then mounted on slides with Merck entellan and studied under a Zeissfluorescence microscope fitted for reflection.

\section{Results}

Catecholamine-containing axons were observed in great number in the periventricular area (thick varicosities), the preoptic periventricular area, the arcuate nucleus (fine, medium and thick varicosities, fig. 1), the medial preoptic nucleus (fig. 2), the premammillary area and the dorso-medial nucleus. Varicosity density was higher In the caudal two-thirds of the arcuate nucleus, where the varicosities frequently displayed a pericellular arrangement (figs. 1,3). In the median eminence there was a weak fluorescence at the level of the external contact zone (with a slight increase from the rostral to the caudal part) and around the deep vessels. Some brightly fluorescent varicosities could be seen at some distance from these vessels.

Catecholamine-containing cell bodies were not found routinely but, in 2 animals their number was sufficient to determine their topography. The majority of these cells (figs 3-6) were scattered within the medio basal hypothalamus, from the retrochiasmatic area (fig. 4) to the post-infundibular eminence. Thick varicosities sometimes terminated close to some of these cell bodies (figs. 5,6 ). In our material some catecholaminecontaining cell bodies were also observed in the postero-dorsal area and in the rostral periventricular area. All these cell bodies showed a weak to medium fluorescence of the dopaminergic type ; they were scattered throughout a wide area and could be classified into three main groups (fig. 7).

FIG. 1. - Catecholamine-containing axons of the medio-basal hypothalamus. Note the thick varicosities (single arrows) and the medium sized varicosities (double arrows) around non-reactive neuronal cell bodies. $C$ : blood capillary. Bar : $10 \mu \mathrm{m}$ ( $\times 600)$.

FIG. 2. - Catecholamine-containing axons of the medial preopfic area. Note the branching axon (a) whose left division (small arrows) give rise to pericellular endings. Bar : $10 \mu \mathrm{m}(\times 600)$.

FIG. 3. - Catecholamine-containing cell body of the medio-basal hypothalamic group. Note the thick varicose endings around non-reactive neuronal cell bodies (arrows). Bar : $10 \mu \mathrm{m}(\times 600)$.

FIG. 4. - Catecholamine-containing cell body of the retro-chiasmatic area. Note the non-reactive nucleus $(n)$ with superimposed fluorescent cytoplasm. Bar : $10 \mu \mathrm{m}(\times 1500)$.

FIG. 5-6. - Catecholamine-contoining cell bodies of the infundibular nucleus with thick fluorescent varicoeistsi (arrows) suggesting axo-somatic synapses. Bar : $10 \mu \mathrm{m}$ ( $\times 1500)$. 

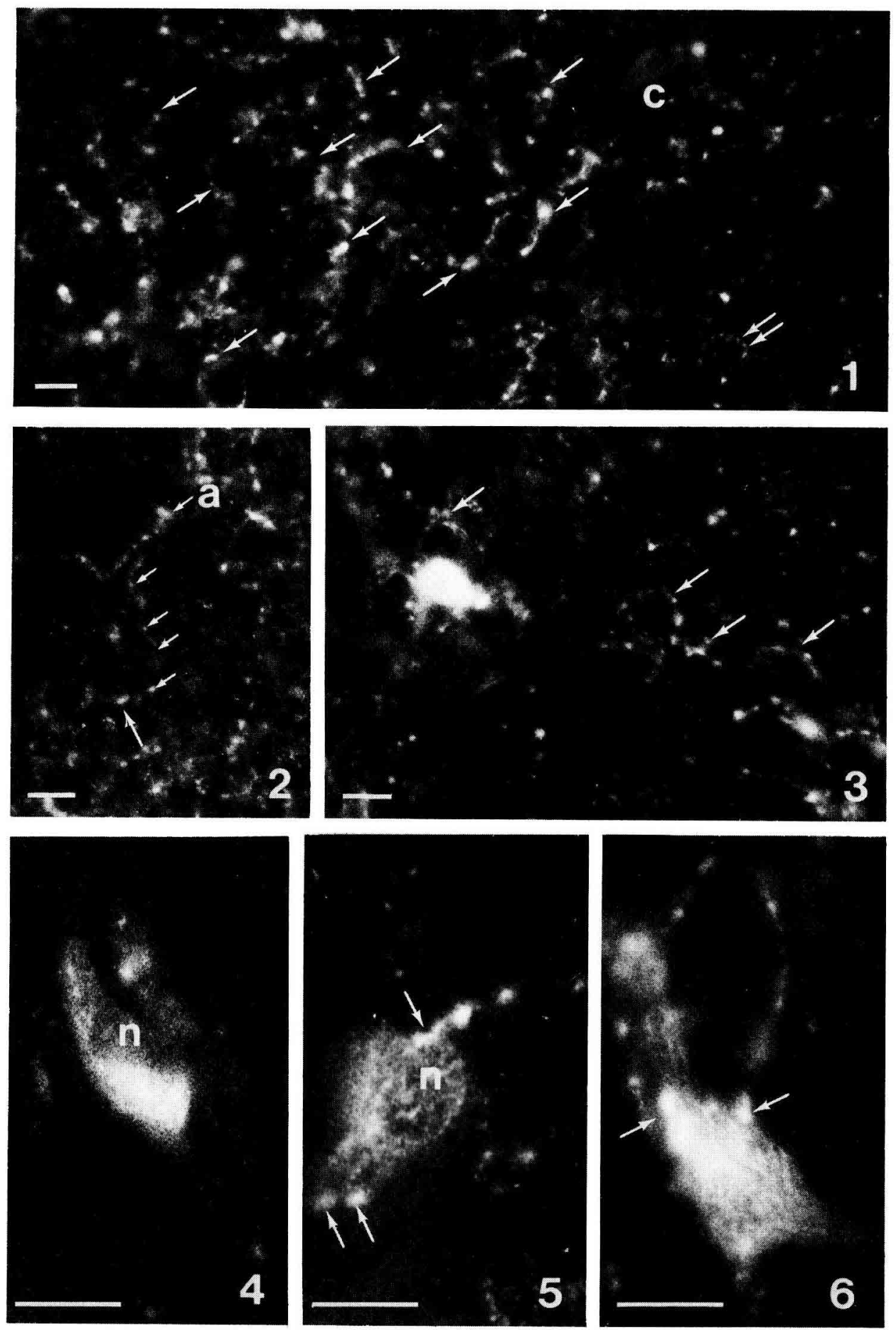


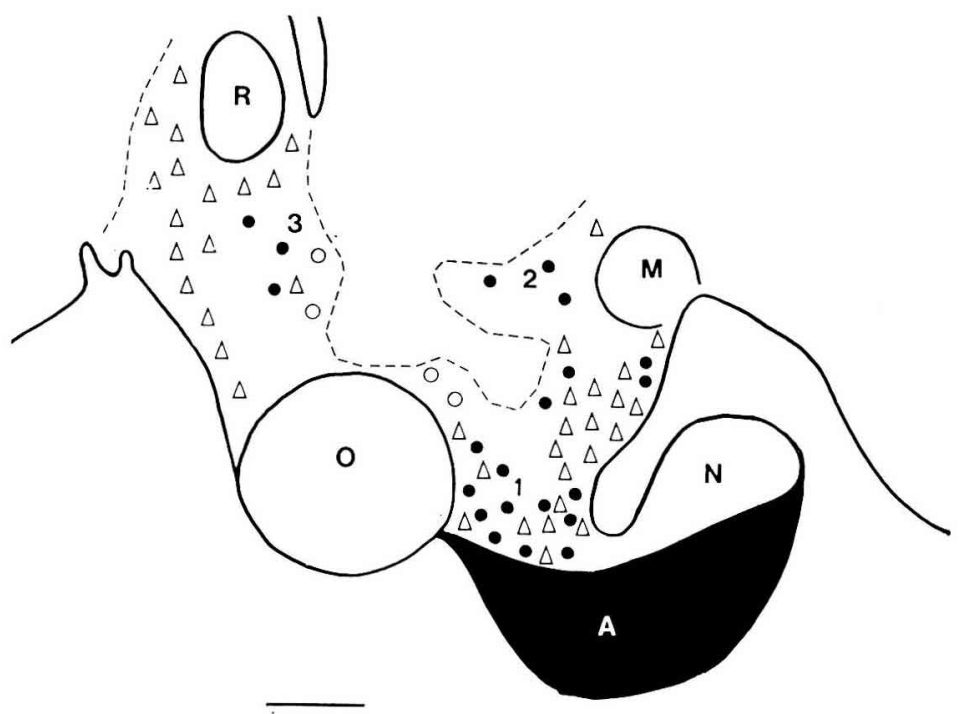

FIG. 7. - Topography of catecholamine-containing cell bodies (black circles) and LRH-producing neurons (white triangles) in the hypothalamus of a normal (untreated) squirrel monkey, projected on midsagittal plane. $M$ : mammillary body ; $N$ : neural lobe ; $O$ : optic chiasm ; $R$ : rostral commissure. 1 : medio-basal hypothalamic group ; 2 : postero-dorsal group ; 3 : rostral group. Bar : $1 \mathrm{~mm}$. Areas containing high number of fluorescent catecholaminergic endings are circumscribed by the dotted line. Yellow fluorescent cell bodies (white circles).

\section{Discussion}

The presence of high densities of catecholamine-containing axons throughout the dispersion area of $\mathrm{LH}-\mathrm{RH}$ reactive perikarya suggest that most of them are at least partly under catecholaminergic control (fig. 7).

In spite of the fact that catecholamine-containing cell bodies are not found routinely in adult monkeys (Felten 1973, 1976 ; Hoffman ef al., 1976 ; Ishikawa and Tanaka, 1977), our observations suggest that they are not localized only within the mediobasal hypothalamus but may also be observed in other hypothalamic areas; this was recently demonstrated by Jacobowitz and McLeod in the pygmy primate, Cebuella pygmaea, where they form three main groups similar to the A12 (infundibular), A13 (incerto-hypothalamic) and A14 (anterior hypothalamic) groups, successively described in rats by Fuxe (1964, 1965), Nobin et al. (1975), Fuxe ef al. (1976), Hökfelt ef al. (1976) and Sladek and McNeil (1977). Taken together these results suggest that hypothalamic catecholamine-containing cell bodies of primates have the same wide dispersion and topographic organization as previously described in rats and confirmed in other mammalian species, particularly mice (Barry, 1969, 1970), guinea pigs (Barry, 1970 ; Leonardelli, 1971), hamsters (Hermand, Leonardelli and Tramu, 1975), rabbits (Bensch ef al., 1975) and cats (Cheung and Sladek, 1975).

The presence of indoleaminergic cell bodies in the hypothalamus of squirrel monkeys as well as in that of rats (Descarries and Beaudet, 1977 ; Chan-Palay, 1977) 
is still an unsolved question. In one of our animals a few indoleaminergic-like cell bodies were observed in the rostral hypothalamus and the retrochiasmatic area (fig. 7), but this must be confirmed by pharmacological experiments.

Reçu en septembre 1978.

Accepié en octobre 1978.

Acknowledgements. - This work was financed by the DGRST (contrat no 76-7-1536) and the UER III of the Faculty of Medicine.

Résumé. Des concentrations importantes d'axones catécholaminergiques de diamètres variables ont été observées avec la technique de Falck et Hillarp dans l'hypothalamus du singe écureuil, notamment la région périventriculaire, le noyau pré-optique, le noyau arqué, l'aire prémammillaire et le noyau hypothalamique dorsomédial.

Les péricaryons de neurones catécholaminergiques ne sont pas visibles chez tous les animaux mais ont pu être observés dans l'hypothalamus médio-basal et les régions rostrale et postéro-dorsale, leur topographie rappelant celle des groupes A12, A13 et A14, décrits chez d'autres Mammifères.

\section{References}

BARRY J., 1969. Recherches sur le rôle des monoamines infundibulaires dans le contrôle de la sécrétion gonadotrope préhypophysaire chez le cobaye et la souris, 245-252. In BARGMANN W., Aspects of neuroendocrinology, Springer Verlag, Berlin.

BARRY J., 1970. Etude en fluorescence U. V. des monoamines des axes hypothalamopréhypophysaires chez divers rongeurs, 60-72. In BENOIT J., KORDON Cl., Neuroendocrinologie, Ed. C.N.R.S. Paris.

BARRY J., CARETTE B., 1975. Immunofluorescence study of LRF neurons in primates Cell Tiss. Res., 164, $163-178$.

BARRY J., CROIX D. 1978. Immunofluorescence study of the hypothalamus-infundibular LRH tract and serum gonadotropin levels in the female squirrel monkey during the estrous cycle. Cell Tiss. Res., 192, 215-226.

BATTISTA A., FUXE K., GOLDSTEIN M., OGAWA M., 1972. Mapping of central monoamines neurons in the monkey. Experientia, 26, 688-690.

BENSCH J., LESCURE H., ROBERT J., FAURE J. M. A., 1975. Catecholamine histofiuorescence in the median eminence of female rabbits activated by mating. J. Neural. Trans., 36, 1-16.

CHAN-PALAY V., 1977. Indoleamine neurons and their processes in the normal rat brain and in chronic dief-induced thiamine deficiency demonstrated by uptake of ${ }^{3} \mathrm{H}$ serotonin. J. comp. Neurol., 176, 467-494.

CHEUNG Y., SLADEK Y. R. Jr., 1975. catecholamine distribution in feline hypothalamus. J. comp. Neurol., 164, 339-360.

DESCARRIES L., BEAUDET A., 1977. Current data on the serotonic innervation of adult rat hypothalamus. In VINCENT J. D., KORDON Cl., Cell biology of hypothalamic neurosecrefory processes, Ed. C.N.R.S. Paris (in press)

FALCK B., HILLARP N. A., THIEME G., TORP A., 1962. Fluorescence of catecholamine and related compounds condensed with formaldehyde. J. Histochem. Cytochem., 10, 348-354.

FETLEN D. L., 1973. The localization of catecholamine-containing and indoleamine containing cell bodies and ferminals in the central nervous system of the squirrel monkey (Saimiri sciureus). M. Thesis. Univ. of Pennsylvania.

FELTEN D. L., 1976. Catecholamine neurons in the squirrel monkey hypothalamus. J. Neural. Trans., 39, 269-280. 
FUXE K., 1964. Cellular localization of monoamines in the median eminence and infundibular stem of some mammals. Z. Zellforsch., 61, 710-734.

FUXE K., 1965. Evidence for the existence of monoamine neurons in the central nervous system. IV. The distribution of monoamine nerve terminals in the central nervous system. Acto physiol. scond., 64, 247-258.

FUXE K., HÖKFELT T., JOHANSSON O., GANTEN D., PEREZ de la MORA M., POSSANI L., TAPIA R., PALACIOS R., SAID S., MUTT V., 1976. Monoamine neuron systems in the hypothalamus and their relation to the GABA and peptide containing neurons, 17-40. In MORNEX R., Neuroendocrinologie, Ed. INSERM, Paris.

HERMAND E., LEONARDELLI J., TRAMU G., 1975. Mecanisme hypothalamique de l'action antiovulatoire du sulpiride. L'Encéphale, 1, 375-382.

HOFFMAN G. E., FELTEN D. K., SLADEK J. R. Jr., 1976. Monoamine distribution in primate brain. III. Catecholamine containing varicosities in the hypothalamus of Macaca mulatta. Amer. J. Anat., 174, 501-505.

HOFFMAN G. E., MELNYK V., HAYES T., BENNETT-CLARKE C., FOWLER E., 1978. Immunocytology of LH-RH neurons, 67-82. In SCOTT D. E., KOZLOWSKI G. P., WEINDL A., Neural hormones and reproduction, Karger, Basel.

HÖKFELT T., JOHANSSON O., FUXE K., GOLDSTEIN M., PARK D., 1976. Immunohistochemical studies on the localization and distribution of monoamine neuron systems in the rat brain. I. Tyrosine hydroxylase in the mes- and diencephalon. Med. Biol., 54, 427-453.

ISHIKAWA M., TANAKA C., 1977. Morphological organization of catecholamine terminals in the diencephalon of the rhesus monkey. Brain Res., 119, 43-55.

JACOBOWITZ D. M., MCLEOD P. D., 1978. A brainstem atlas of catecholaminergic neurons and serotoninergic perikerya in a pigmy primate (Cebuella pigmaea). J. comp. Neurol., 117, 397 416.

LEONARDELLI J., 1971. Monoamines et fonction gonadotrope, 109-127. In HERLANT M. Fonction gonadotrope ef rapports hypothalamo-hypophysaires chez les animaux sauvages, Masson, Paris.

MAZZUCA M., 1977. Immunocytochemical and ultrastructural identification of luteinizing hormonereleasing hormone (LH-RH) containing neurons in the vascular organ of the lamina terminalis (OVLT) of the squirrel monkey. Neurosc. Letf., 5, 123-127.

NOBIN A., BJÖRKLUND A., 1973. Topography of the monoamine neuron system in the human brain as revealed in fetuses. Acfa physiol. scand., suppl. 388, 1-40.

NOBIN A., BJÖRKLUND A., LINDVALL G., 1975. A new dopamine neuron system in rat hypothalamus. Acla endocr., 80, suppl. 199, 133-145.

SILVERMAN A. J., ANTUNES J. L., FERIN M., ZIMMERMAN E. A., 1977. The distribution of luteinizing hormone-releasing hormone (LH-RH) in the hypothalamus of the rhesus monkey. Light microscopic studies using an immunoperoxidase technique. Endocrinology, 101, 134-142.

SLADEK J. R., McNEILL T. H., 1977. Fluorescence histochemical identification of monoamine containing subependymal cells in the mammalian and ovarian diencephalon. J. Hisfochem. Cyfochem., 25, 241 (abstr.).

ZIMMERMAN E. A., ANTUNES J. L., 1976. Organization of the hypothalamic pituitary system : Current concepts from immunohistochemical studies. J. Histochem. Cytochem., 24, 807-815. 